\title{
VISUAL ACUITY AND CONTRAST SENSITIVITY DEPENDING FROM KERATOCONUS APEX POSITION
}

\author{
Sanita Lìduma ${ }^{\#}$ and Gunta Krūmiṇa \\ Department of Optometry and Vision Science, Faculty of Physics and Mathematics, University of Latvia, \\ 1 Jelgavas Str., LV-1004, Rīga, Latvia \\ \# Corresponding author, sanita.liduma@gmail.com
}

Communicated by Ivars Lācis

\begin{abstract}
Various studies have demonstrated that patients with keratoconus have significant loss of contrast sensitivity while its value varies in different studies. None of these studies has analysed reduced contrast sensitivity depending on the position of apex of corneal conus. Visual acuity and contrast sensitivity were evaluated for patients with keratoconus using the FrACT software. Contrast sensitivity was assessed at the following frequencies: 1, 3, 5, 7, 9, 11, 13, and 15 cycles per degree (cpd). Twenty-four eyes with keratoconus were analysed. Contrast sensitivity was significantly lower for patients with the apex at the centre compared with apex on the periphery both with $(\mathrm{p}=0.0078)$ and without $(\mathrm{p}=0.0078)$ spectacle correction. For patients with the apex at the centre, contrast sensitivity was significantly different with and without correction (0.02); however, there was no difference for patients with apex on the periphery $(p=0.06)$. The results showed that if the keratoconus apex is at the centre, then spectacle correction improves contrast sensitivity at lower spatial frequencies $(1,3$, and $5 \mathrm{cpd})$, while it remains unchanged at medium and high spatial frequencies. If the keratoconus apex is on the periphery, spectacle correction does not improve contrast sensitivity.
\end{abstract}

Key words: keratoconus, apex at the centre, apex on the periphery, contrast sensitivity.

\section{INTRODUCTION}

Keratoconus is a bilateral, progressive, non-infectious corneal disease that often creates a large myopia and astigmatism (Rabinowitz, 1998). Keratoconus incidence is 1 of 2000 persons. Keratoconus is a multifactorial disease of unknown etiology, which impairs visual quality of the cornea because of thinning and protrusion, resulting in an irregular astigmatism with or without myopia (Jadidi et al., 2015). Change of corneal shape for keratoconus patients can change the optical quality of the eye and retinal image quality. For keratoconus patients, both ocular and a high degree of corneal aberrations are significantly higher compared to that in a normal patient's eye. Not only aberrations but also changes of cornea tissue opacity may lead to poor quality of the image on the retina. Because of these corneal tissue changes, contrast sensitivity in keratoconus patients is reduced by light scattering (Jinabhai et al., 2012). Early diagnosis of keratoconus is possible because of accurate image acquisition with a computerised topographic which includes corneal curvature and elevation analysis (Stein and Stein, 2011). There are I, II, III, and IV keratoconus grades according to the Amsler-Krumich classification.

Keratoconus is a disease that affects many young patients, who have to live with the disease for the rest of their lives
(Kyme et al., 2004; Kyme et al., 2008). For keratoconus patients, it is impossible to evaluate the quality of life only by clinical data (Kyme et al., 2004). Studies have shown that the quality of life for patients with keratoconus is reduced more if changes in corneal curvature radius increase and high-contrast visual acuity decreases. Patients have worse quality of life if the visual acuity is less than 20/40 and corneal curvature $\geq 52$ D (Kyme et al., 2008). However, studies have shown that high-contrast visual acuity is not always related to the patient's life satisfaction and highcontrast visual acuity measurement is not the best estimate of visual function, because patients can distinguish and read high-contrast Snellen 20/20 optotype even if the letters have big distortion (de Freitas Santos Paranhos et al., 2011). Patient satisfaction with their quality of life can be affected by the following factors: gender (men were more satisfied with their lives than women), cylinder size (at least $1.00 \mathrm{D}$ cylinder reduction improved the patients' quality of life), and contrast sensitivity at 3 and 6 cpd frequencies (de Freitas Santos Paranhos et al., 2010). Studies have shown that changes in contrast sensitivity are not predictable from visual acuity examination in high-contrast conditions (Carney and Lembach, 1991). A contrast sensitivity measurement is an important subjective visual quality measurement for keratoconus patients. 
In patients with good vision, the contrast sensitivity curve peak is in the medium spatial frequencies (3-6 cpd), with a steeper decline in the high spatial frequencies and flatter at the lowest frequencies (Owsley, 2003). Contrast sensitivity at frequencies of 3 and $6 \mathrm{cpd}$ are more important for object recognition, and frequencies between 6 and $12 \mathrm{cpd}$ are important for reading (de Freitas Santos Paranhos et al., 2010). Contrast sensitivity at high frequencies is correlated with Snellen visual acuity and contrast sensitivity at low frequencies is not related to the Snellen visual acuity (Brown and Lovie-Kitchin, 1989; Kennedy and Dunlap, 1990). Before visual acuity reduction, decreases in contrast sensitivity at medium and high frequencies have been observed in keratoconus patients. Even with high Snellen visual acuity, contrast sensitivity for keratoconus patient can be significantly reduced (Marsack et al., 2007). Many studies have shown that, in patients with keratoconus, contrast sensitivity was substantially reduced if compared to patients without corneal pathology (Jinabhai et al., 2012). Studies have reported different values for decrease of contrast sensitivity. However, there are no studies in which contrast sensitivity has been analysed depending on keratoconus apex localisation, which might explain the different results of previous studies.

\section{MATERIALS AND METHODS}

Participants. The study included 14 keratoconus patients (24 eyes) with keratoconus. Keratoconus has four grades of development. The present study examined only patients with grades I, II, and III. The keratoconus apex is in the area where the cornea has the highest value of the curvature. The cornea vertex usually is located below the visual axis. If the keratoconus apex is in $1.5 \mathrm{~mm}$ large radius around the centre of the pupil then we assumed that the keratoconus apex was at the centre. If the apex was outside the circle with 3 mm diameter then we assumed that the apex was located at the periphery of the cornea (see Fig. 1).

Nine patients with keratoconus apex at the centre and 15 with keratoconus apex on the periphery participated in the research. There were seven patients with keratoconus I,

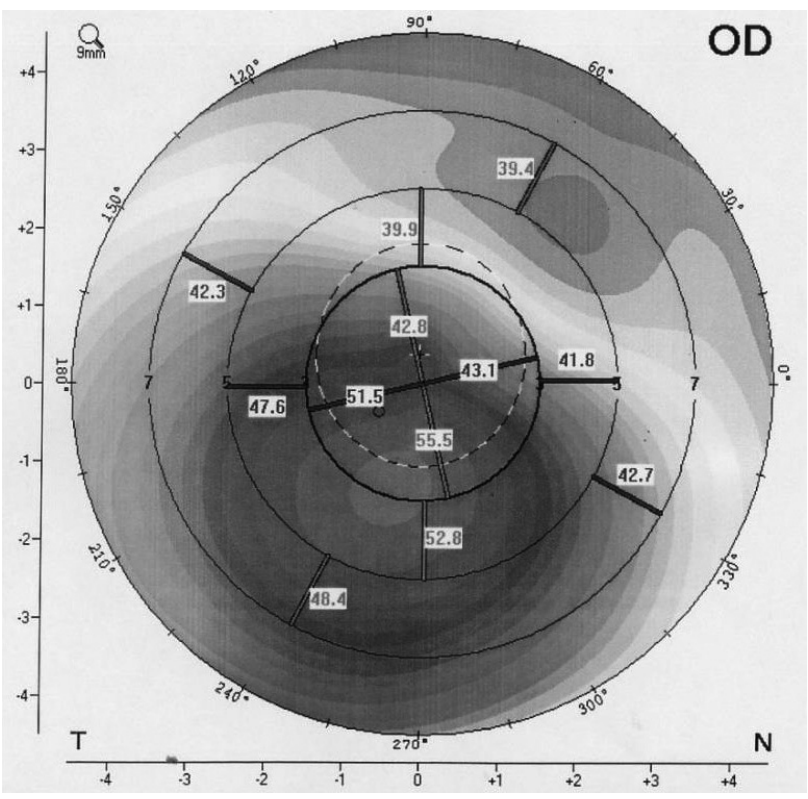

Fig. 1. Corneal topography changes in corneal curvature. The central circular black line shows the centre area for cornea around the visual axis. The dashed circle shows the size of the pupil region.

seven with keratoconus II, and ten with keratoconus III (Table 1). Figure 2 shows an example for a keratoconus patient with the apex at the centre and on the periphery.

Table 1

DISTRIBUTION OF PATIENTS DEPENDING ON APEX LOCALIZATION AND KERATOCONUS GRADE

\begin{tabular}{c|c|c}
\hline Grade & Apex at the centre & Apex on the periphery \\
\hline I & 1 & 6 \\
II & 1 & 6 \\
III & 7 & 3
\end{tabular}

Patients in the study were selected using the following criteria:

- cornea without opacity;

- patients with age from 18 to 40 years;

- at least half a year since a cross-linking operation.
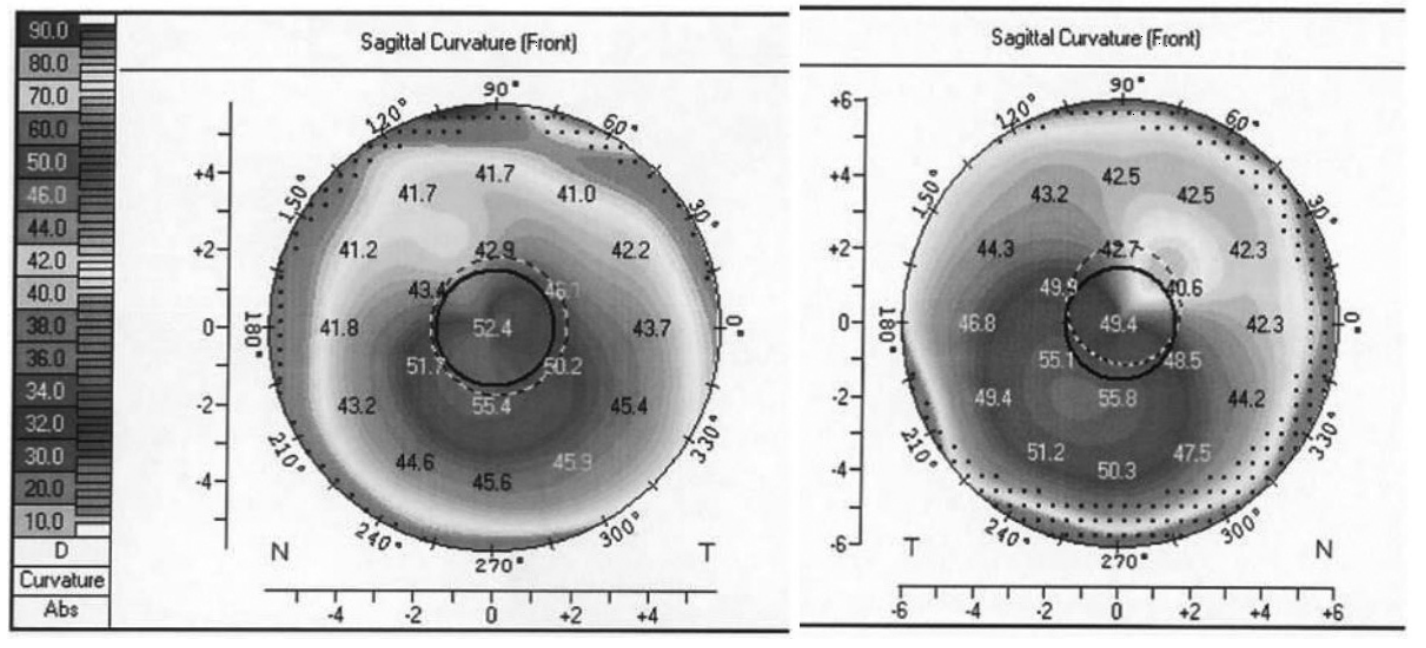

Fig. 2. The left image is for a patient's topography with the keratoconus apex at the centre and the right with the keratoconus apex on the periphery. 
The following tests were made for patients:

- the best possible subjective refraction correction;

- visual acuity with and without refractions correction;

- corneal topography;

- measurement of pupil size in twilight conditions;

- biomicroscopy to exclude patients with opacities;

- contrast sensitivity with and without correction;

- questionnaire with 25 questions to assess quality of life of patients. The questionnaire was developed in the National Eye Institute: Visual Functioning Questionnaire-25 (VFQ-25).

Visual acuity and contrast sensitivity was measured at $3 \mathrm{~m}$ with and without the best possible spectacle correction using the FrACT software 3.9.3 (Bach, 2007). The grating contrast sensitivity test was used and measurements were taken at the following frequencies: 1, 3, 5, 7, 9, 11, 13, and $15 \mathrm{cpd}$. We classified 1 and $3 \mathrm{cpd}$ as low frequencies; 5, 7, and $9 \mathrm{cpd}$ as medium frequencies, and 11, 13, and $15 \mathrm{cpd}$ as high frequencies. Contrast sensitivity was measured taking 10 measurements in four directions using the psychometric method, and visual acuity was measured using the $\mathrm{C}$ optotype. Visual acuity measurements started with $\mathrm{C}$ optotype recognition and depending on the patient response, the sizes were increased or reduced. For all patients, visual acuity and contrast sensitivity were measured only at one time. To compare contrast sensitivity for patients with keratoconus to patients without corneal pathology, we measured contrast sensitivity also for a patient without pathology. These measurements were taken only one once per patient. Measurements were done in 10 lux illuminance to control pupil size and to ensure that the patient looks through the central part of the pupil. Illuminance was measured with a Konica Minolt T-10M luxometer. Contrast sensitivity was measured on the computer display at $3 \mathrm{~m}$ distance by 10 consecutive measurements. Average luminance from the computer display was $99 \mathrm{~cd} / \mathrm{m}^{2}$ and luminance from surrounding

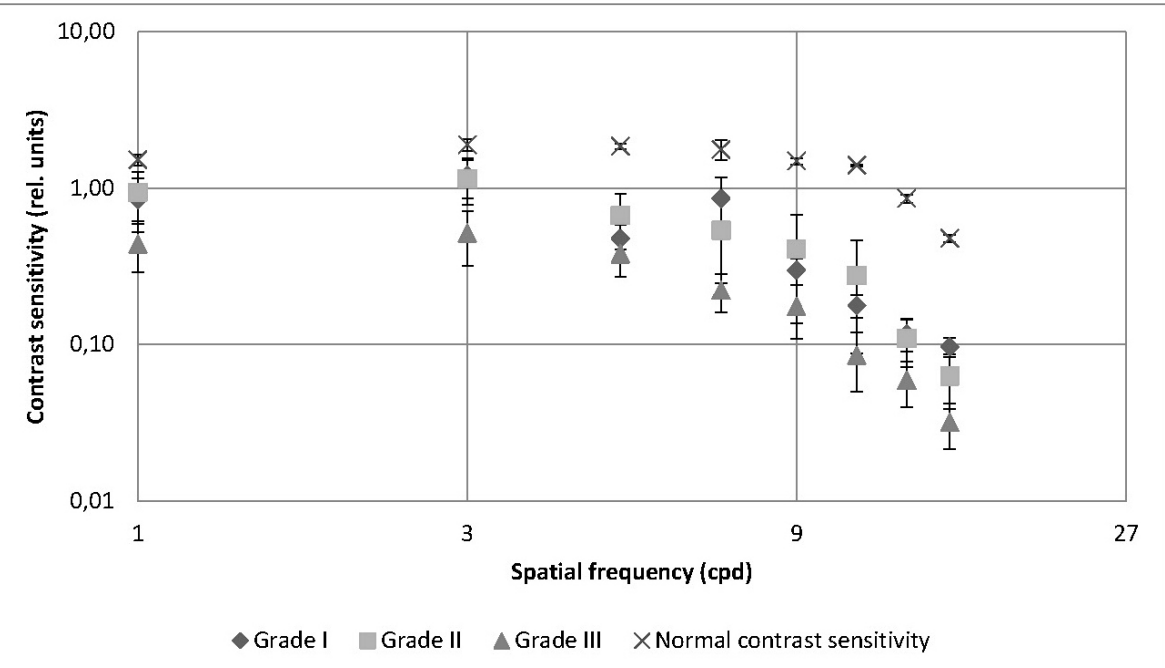

Fig. 3. Contrast sensitivity depending on keratoconus grade (relat. units \pm standard error). walls was $0.83 \mathrm{~cd} / \mathrm{m}^{2}$. Luminance was measured with a Konica Minolta Chroma meter CS-100A.

\section{RESULTS}

In previous studies (Hess and Carney, 1979; Zadnik et al., 1984; Zadnik et al., 1987; Jinabhai et al., 2012) on evaluation of contrast sensitivity for keratoconus patients, common trends were not found; contrast sensitivity was reduced at medium and high spatial frequencies, but the reduction began at different frequencies. If data are analysed by keratoconus grade, then contrast sensitivity does not show common trends. For each patient, contrast sensitivity reduction appears at different spatial frequencies (see Fig. 3), but we expected that with greater keratoconus grade contrast sensitivity reduction would start already at medium spatial frequencies. In Figure 3, contrast sensitivity curves for keratoconus patients are compared with contrast sensitivity in a patient without corneal pathology. Figure 3 shows the lowest contrast sensitivity occurred in patients with keratoconus III grade, but contrast sensitivity was reduced in all patients.

Average corrected visual acuity and standard error for the keratoconus I grade was $0.71 \pm 0.45$ decimal units, compared to $0.38 \pm 0.15$ decimal units without correction. Average corrected visual acuity and standard error for the keratoconus II grade was $0.67 \pm 0.11$ decimal units and without correction $-0.55 \pm 0.15$ decimal units. Average corrected visual acuity and standard error for the keratoconus III grade was $0.41 \pm 0.07$ decimal units and without correction $-0.17 \pm 0.06$ decimal units.

Different contrast sensitivity curves were obtained depending on keratoconus apex localisation (see Fig. 4). Contrast sensitivity in patients with correction was higher for patients with the keratoconus apex on the periphery than for patients with the keratoconus apex at the centre. Deviation in contrast sensitivity in keratoconus patients, compared to normal conditions, starts with spatial frequency $5 \mathrm{cpd}$. The difference between patients with the keratoconus apex at the 


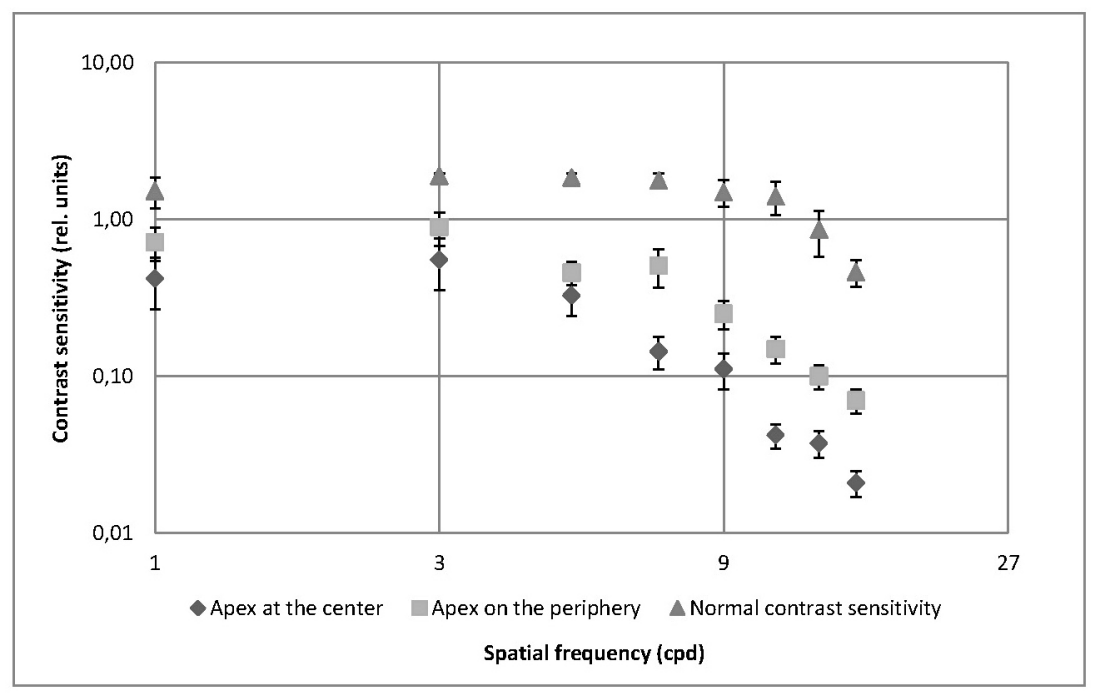

Fig. 4. Contrast sensitivity with correction for keratoconus patients, depending on the localisation of the apex at the centre and on the periphery. Standard errors are shown for data points. centre and on the periphery starts with spatial frequency 7 cpd.

The Wilcoxon signed rank test showed statistically significant difference for keratoconus patients with correction from the normal contrast sensitivity curve with apex at the centre $(p=0.078)$ and apex at the periphery $(p=0.0078)$ with the significance level $p \leq 0.05$, and also between keratoconus patients with the apex at the centre and on the periphery $(p=0.0078)$.

Average visual acuity and standard error for patients with the keratoconus apex at the centre was $0.35 \pm 0.05$ decimal units, compared to $0.66 \pm 0.07$ decimal units when the apex was on the periphery.

Contrast sensitivity for patients without correction showed larger differences between keratoconus patients with apex at the centre and on the periphery (see Fig. 5). At all the spatial frequencies, higher contrast sensitivity was observed in patients with the keratoconus apex on the periphery compared with patients with apex at the centre. Improvement was seen at all the spatial frequencies, and contrast sensitivity with apex on the periphery was more similar to the normal contrast sensitivity curve.
The Wilcoxon signed rank test showed significant difference for keratoconus patients without correction from the normal contrast sensitivity curve with apex at the centre $(p=0.0078)$ and apex on the periphery $(p=0.0078)$ with the significance level $p \leq 0.05$. Also, there was a significant difference between keratoconus patients with the apex at the centre and on the periphery $(p=0.0078)$ without refraction correction.

Average visual acuity and standard error for patients without correction with the keratoconus apex at the centre was $0.14 \pm 0.04$ decimal units, compared to $0.52 \pm 0.10$ decimal units with the apex on the periphery.

For keratoconus patients with the apex at the centre, correction improved contrast sensitivity at low spatial frequencies and the highest improvement was for spatial frequency 3 cpd, but it was lower compared with contrast sensitivity for a patient without eye pathologies (see Fig. 6).

The Wilcoxon signed rank test showed significant differences in contrast sensitivity curve changes in keratoconus patients with and without correction with the apex at the centre $(p=0.02)$ with the significance level $p \leq 0.05$. There was a significant difference between normal contrast sensi-

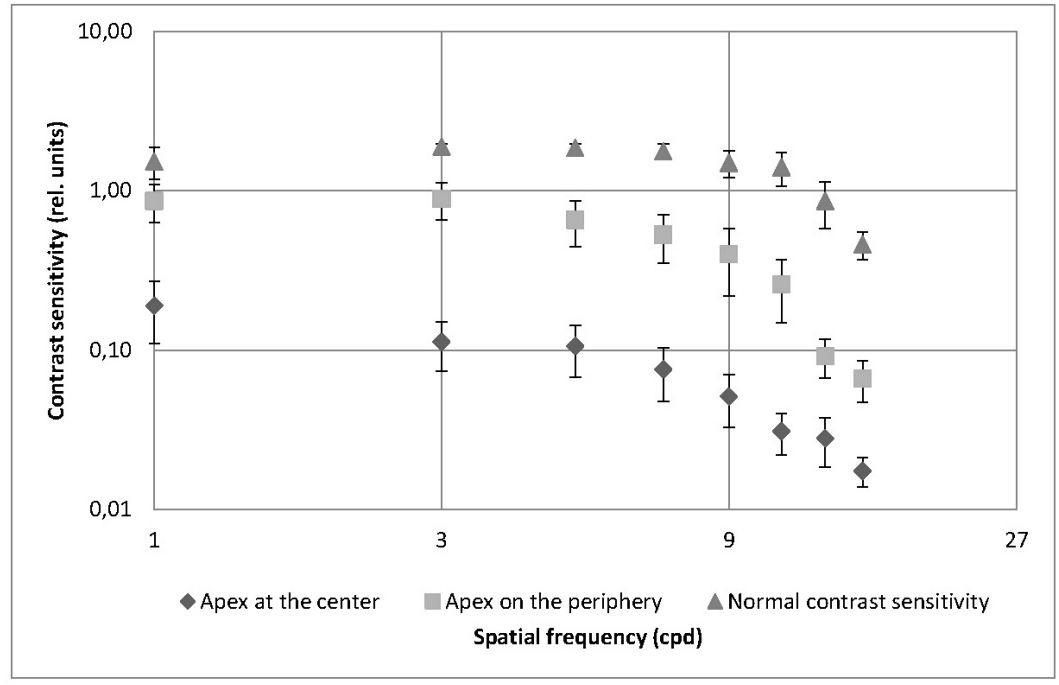

Fig. 5. Contrast sensitivity without correction if keratoconus apex is at the centre and on the periphery. Standard errors are shown for data points. 


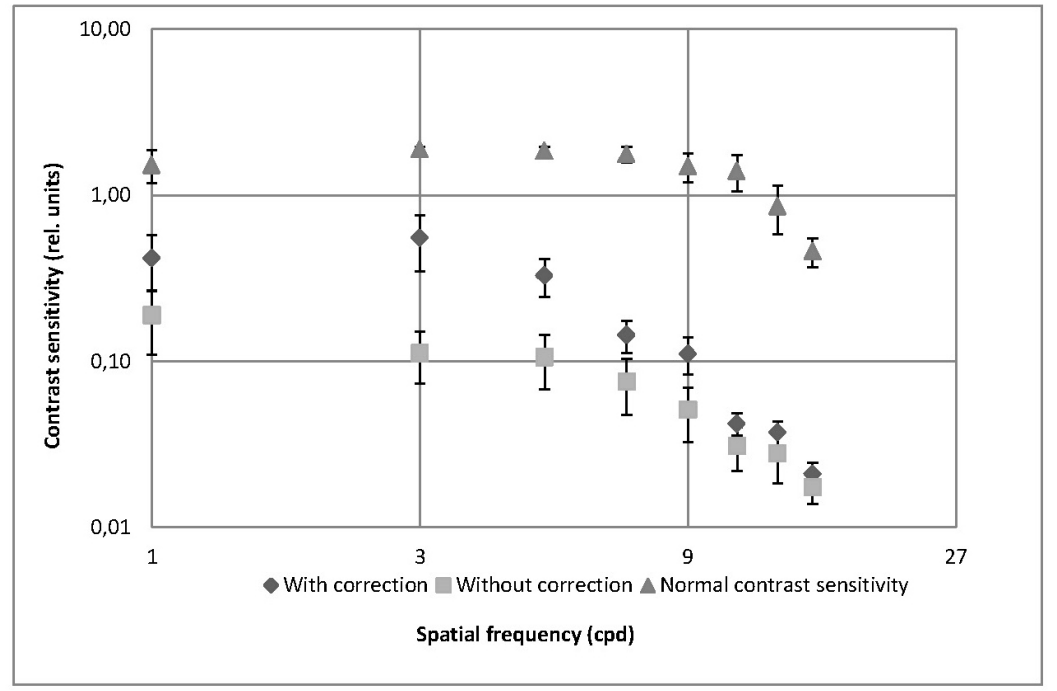

Fig. 6. Contrast sensitivities changes for patients with the keratoconus apex at the centre with and without correction. Standard errors are shown for data points. tivity and contrast sensitivity for keratoconus patients with $(p=0.0078)$ and without $(p=0.0078)$ correction.

Average visual acuity and standard error for patients with correction was $0.35 \pm 0.05$ decimal units and without correction $-0.14 \pm 0.04$ decimal units.

For patients with the keratoconus apex at the periphery, there was a completely different situation (see Fig. 7), as correction did not improve contrast sensitivity but worsened contrast sensitivity at frequencies $1,5,7,9$, and $11 \mathrm{cpd}$ (Fig. 7).

The Wilcoxon signed rank test showed no significant difference in keratoconus patients with apex on the periphery for contrast sensitivity curve changes with and without correction $(p=0.06)$ with the significance level $p \leq 0.05$, but there was a significant difference between normal contrast sensitivity and contrast sensitivity with correction $(p=0.0078)$ and without correction $(p=0.0078)$.

Average visual acuity patients with the keratoconus apex on the periphery with correction was $0.66 \pm 0.07$ decimal units, compared to $0.52 \pm 0.10$ decimal units without correction.
To verify that the asymmetric distribution in grades of patients did not affect results, we compared patients with keratoconus in the keratoconus III grade. Figure 8 shows a comparison between seven patients with apex at the centre and three patients with the apex on the periphery. Contrast sensitivity was larger for patients with the apex at the periphery compared to patients with the apex at centre of the cornea.

Visual acuity and contrast sensitivity correlation. In previous studies on patient life quality, patient experience of life quality decreased if contrast sensitivity decreased at spatial frequencies 3 and 6 cpd (de Freitas Santos Paranhos et al., 2010). Moreover, previous studies (de Freitas Santos Paranhos et al., 2010; Jinabhai et al., 2012) showed that a bigger difference in contrast sensitivity occurred at these frequencies, compared to that in participants without pathologies, and the biggest difference occurred between patients with the apex at the centre and the apex on the periphery.

Correlation coefficients varied between visual acuity and spatial frequencies. The biggest exponential correlation was between visual acuity at spatial frequency $3 \mathrm{cpd}$ and fre-

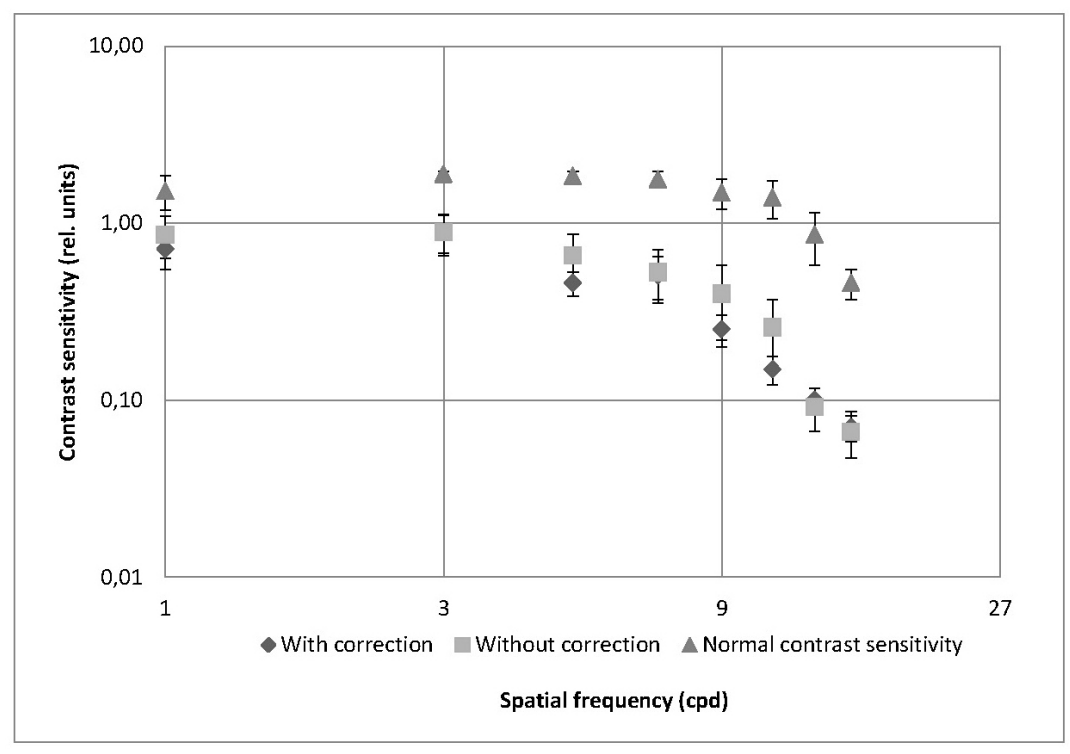

Fig. 7. Contrast sensitivities changes for patients with the keratoconus apex on the periphery with and without correction. Standard errors are shown for data points. 


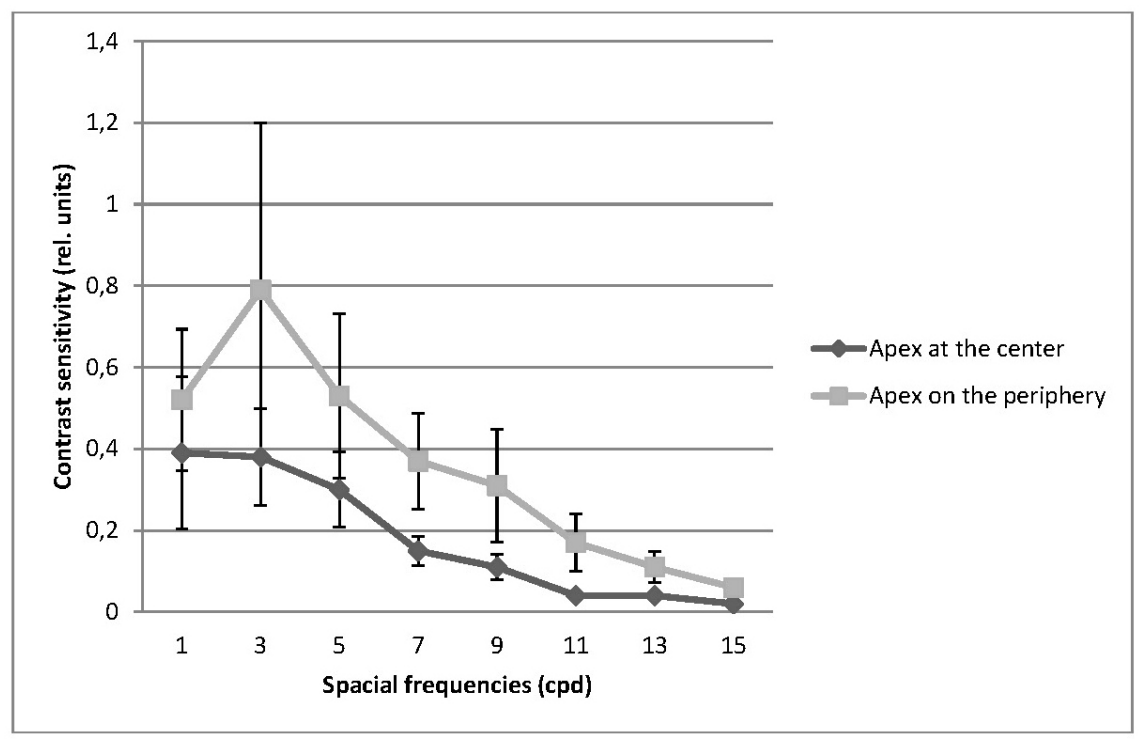

Fig. 8. Contrast sensitivities comparison between grade III keratoconus patients with different apex localisation. Standard errors are shown for data points. quency $5 \mathrm{cpd}(0.83$ and 0.85 , respectively) for patients with the keratoconus apex at the centre. Contrast sensitivity did not change in patients whose visual acuity did not exceed 0.40 decimal units, but correlations were higher for visual acuity higher than 0.40 decimal units. This showed that contrast sensitivity is not decreased due to low visual acuity in patients, and that similar visual acuities can be associated with differing contrast sensitivity.

Analysis of patient questionnaires. Patients with keratoconus apex at the centre answered that in daily activities they feel more difficulties than patients with apex on the periphery. They feel more difficulties when they are reading newspaper, cooking, sewing, repair household things at home, and evaluate human reaction when they have conversation. The situation was better in patients that had the keratoconus apex at the centre in one eye and in the second on the periphery, then in patients with the keratoconus apex on the periphery in both eyes. Also similar answers were observed for patients when they assessed activities at distance, like reading names of streets or names of shops or when patients were going to parties or restaurants, going to cinema or conducting sports activities and driving a car.

There was no difference in individual contrast sensitivity curves for patients with subjective difficulties. We expected that there would be lower contrast sensitivity with greater difference from normal contrast sensitivity curves at medium and high spatial frequencies for patients with subjective difficulties. Average contrast sensitivity difference from normal contrast sensitivity is shown for keratoconus patients at all spatial frequencies with spectacle correction (Fig. 9) and without spectacle correction (Fig. 10). Figure 9 shows that a larger difference from normal contrast sensitivity using spectacle correction occurred at lower spatial frequencies (5, 7 and $9 \mathrm{cpd}$ ) and for a larger difference for patients with the apex at the centre compared with patients with the apex on the periphery. Figure 10 shows a larger deviation from normal contrast sensitivity in patients with the apex at the centre at lower spatial frequencies $(3,5$, and 7 cpd), but with the apex on the periphery greater difference occurred at spatial frequencies 5,7 , and $11 \mathrm{cpd}$.

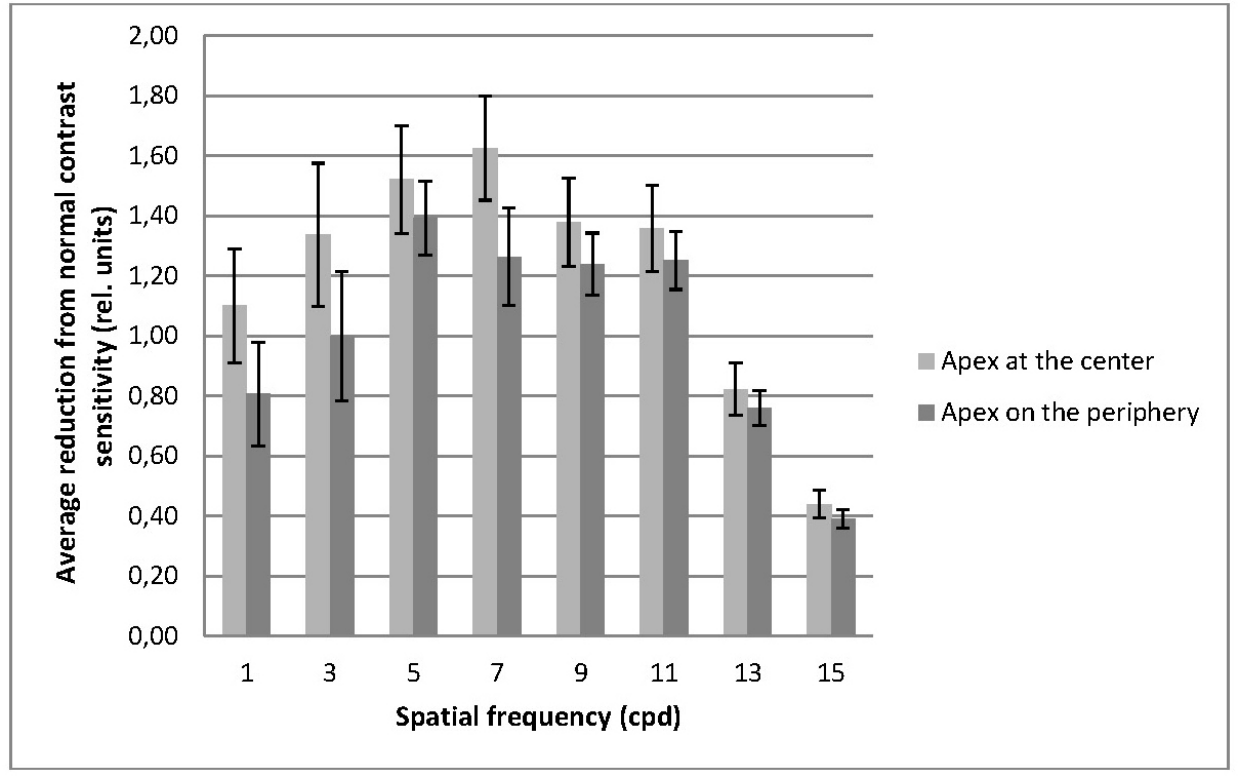

Fig. 9. Average contrast sensitivity difference from normal contrast sensitivity for all spatial frequencies in keratoconus patients with spectacle correction. Standard errors are shown for data points. 


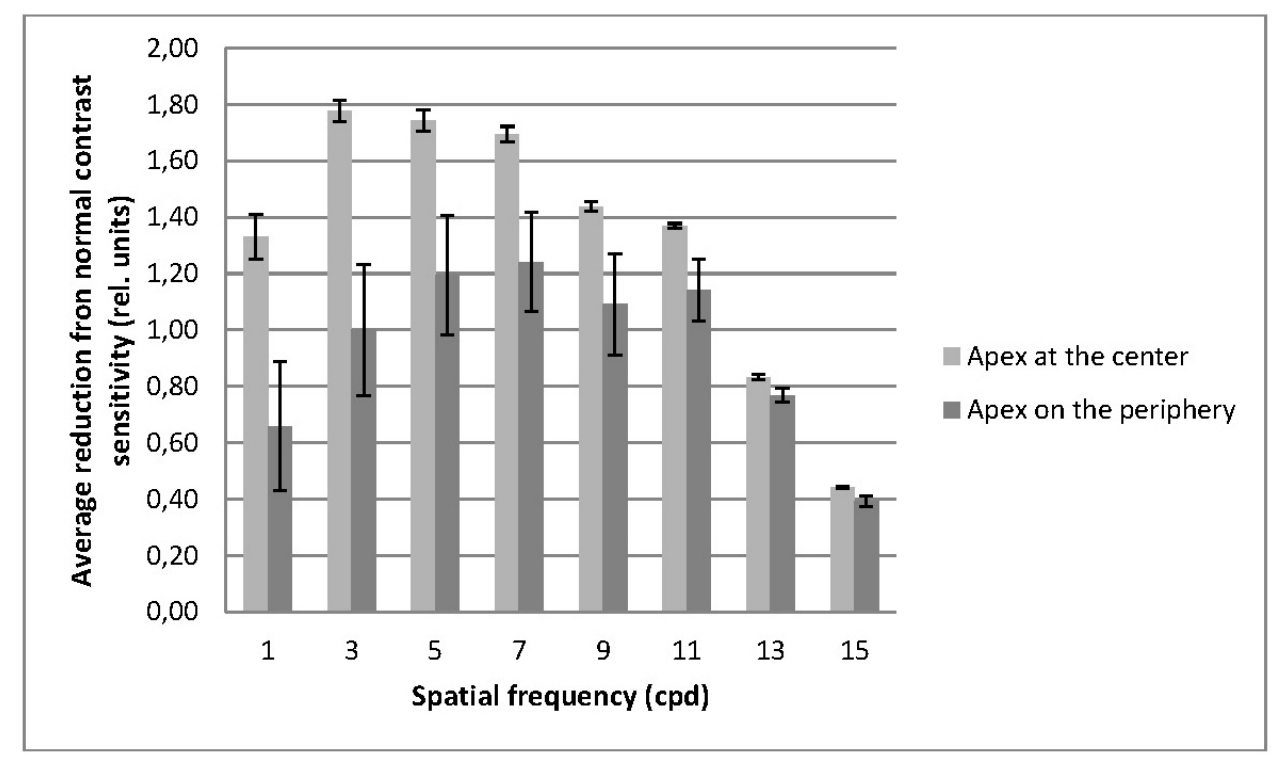

Fig. 10. Average contrast sensitivity difference from normal contrast sensitivity for all spatial frequencies in keratoconus patients without spectacle correction. Standard errors are shown for data points.

\section{DISCUSSION}

Previous studies have shown that contrast sensitivity reduction differs between keratoconus patients, all of the studies showed that for keratoconus patients contrast sensitivity was lower at medium and high spatial frequencies (Hess \& Carney, 1979; Zadnik et al., 1984; Zadnik et al., 1987; Jinabhai et al., 2012). There are no studies on contrast sensitivity depending on apex localisation. In our study we found that for patients with the keratoconus apex at the centre, contrast sensitivity starts to reduce at medium spatial frequencies, but for patients with apex on the periphery only at high frequencies.

The acquired data in our study showed that contrast sensitivity for keratoconus patients starts to reduce at medium spatial frequencies (at frequency $5 \mathrm{cpd}$ ), compared to a normal contrast sensitivity curve. This difference occurred both for patients with the keratoconus apex at the centre and at the periphery. This shows that apex localisation does not define the frequency at which the reductions start.

The greatest difference from normal contrast sensitivity was seen for patients whose contrast sensitivity curve was measured without spectacle correction. For patients with the apex at the centre the best contrast sensitivity improvement with correction was observed at spatial frequency $3 \mathrm{cpd}$, but at higher frequencies the difference between contrast sensitivities decreased. Previous studies demonstrated that patients note more strongly changes at spatial frequencies 3 and $5 \mathrm{cpd}$, compared to that at other frequencies. That is why, in patients with the apex at the centre, correction improved quality of vision. For patients with the apex on the periphery, there was a different situation, as correction did not improve contrast sensitivity.

In our study we cannot explain the effect of corrections on contrast sensitivity. We think that the effect might be explained by a rise in the cornea in the pupil area. If the pupil is at the centre then the rise in the cornea is higher and is rapid in the pupil area, making the image to retina diffuse, which is difficult to correct with spectacle correction. However, the results show a different situation. Also corneas with the apex at the periphery have smoother tissues in the pupil area, which might explain why these patients could correct better, but again this is not consistent with the acquired results. Patients with the apex in the centre had visual acuity improvement about 0.21 decimal lines and patients with apex on the periphery have improvement about 0.14 decimal lines.

Previous studies showed that contrast sensitivities frequencies 3 and 6 cpd were more important for patient life quality. Also, contrast sensitivity correlation with visual acuity is the highest with and without correction for spatial frequencies 3 and $5 \mathrm{cpd}$. That can explain why improving visual acuity particularly improved contrast sensitivity at spatial frequency $3 \mathrm{cpd}$ the the case when the apex was at the centre. With the apex on the periphery, visual acuity does not have high correlation with contrast sensitivity, compared with the case when apex at the centre. This shows that visual acuity is not well associated with contrast sensitivity and that a decrease in contrast sensitivity in keratoconus patients does not depend on decreased visual acuity. Correlation with visual acuity differed depending on spatial frequency.

Previous studies have shown that clinical data are not well associated with patient life quality and how a patient lives with the disease. That is why we gave the questionnaire to evaluate vision quality differences for patients with the apex at the centre and on the periphery. Patients with the apex at the centre had greater difficulties in daily activities than patients with the apex on the periphery. Patients who had different apex localisation in each eye had fewer difficulties than patients with the apex at the centre in both of the eyes.

\section{CONFLICTS OF INTEREST}

The authors have no conflicts of interest to disclose. 


\section{REFERENCES}

Bach, M. (2007). The Freiburg Visual Acuity Test-Variability unchanged by post-hoc re-analysis. Graefe's Arch. Clin. Exper. Ophthalmol., 245 (7), 965-971.

Brown, B., Lovie-Kitchin, J. E. (1989). High and low contrast acuity and clinical contrast sensitivity tested in a normal population. Optom. Vis. Sci., 66 (7), 467-473.

Carney, L. G., Lembach, R. G. (1991). Management of keratoconus: Comparative visual assessments. CLAO J., 17 (1), 52-58.

de Freitas Santos Paranhos, J., Avila, M. P., Paranhos, A. Jr., Schor, P. (2010). Evaluation of the impact of intracorneal ring segments implantations on the quality of life of patients with keratoconus using the NEI-RQL (National Eye Institute Refractive Error Quality of life) instrument. Brit. J. Ophthalmol., 94 (1), 101-105.

de Freitas Santos Paranhos, J., Paranhos, Jr. A., Avila, M. P., Schor, P. (2011). Analysis of the correlation between ophthalmic examination and quality of life outcomes following intracorneal ring segment implantation for keratoconus. Arquivos Brasileiros de Oftalmologia, 74 (6), 410-413.

Hess, R. F., Carney, L. G. (1979). Vision through an abnormal cornea: A pilot study of the relationship between visual loss from corneal distortion, corneal edema, keratoconus, and some allied corneal pathology. Investig. Ophthalmol. Vis. Sci., 18 (5), 476-83.

Jinabhai, A., O’Donnell, C., Radhakrishnan, H., Nourrit, V. (2012). Forward light scatter and contrast sensitivity in keratoconus patients. Contact Lens Anterior Eye, 35 (1), 22-27.

Received 22 September 2016

Accepted in the final form 19 July 2017
Kennedy, R. S., Dunlap, W. P. (1990). Assessment of the Vistech contrast sensitivity test for repeated-measures applications. Optom. Vis. Sci., 67 (4), $248-251$.

Kymes, S. M., Walline, J. J., Zadnik, K., Gordon, M. O., the Collaborative Longitudinal Evaluation of Keratoconus (CLEK) Study Group. (2004). Quality of life in keratoconus. Amer. J. Ophthalmol., 138 (4), 527-535.

Kymes, S. M., Walline, J. J., Zadnik, K., Sterling, J., Gordon, M. O., on behalf of the Collaborative Longitudinal Evaluation of Keratoconus (CLEK) Study Group. (2008). Changes in the quality of life of people with keratoconus. Amer. J. Ophthalmol., 145 (4), 611-617.

Marsack, J. D., Parker, K. E., Pesudovs, K., Donnelly, W. J. 3rd., Applegate, R. A. (2007). Uncorrected wavefront error and visual performance during RGP wear in keratoconus. Optom. Vis. Sci., 84 (6), 463-469.

Owsley, C. (2003). Contrast sensitivity. Ophthalmol. Clin. North Amer., 16 (2), 171-177.

Rabinowitz, Y. S. (1998). Keratoconus. Survey Ophthalmol., 42 (4), 297-319.

Stein, R., Stein, R. (2011). Corneal collagen crosslinking: A major breakthrough in the management of keratoconus, pellucid marginal degeneration, and ectasia after LASIK. Ophthalmol. Rounds, 9 (1), 1-5.

Jadidi, K., Mosavi, S. A., Nejat, F., Naderi, M., Janani, L., Serahati, S. (2015). Intrastromal corneal ring segment implantation (Keraring $355^{\circ}$ ) in patients with central keratoconus: 6-month follow-up. J. Ophthalmol., doi: $10.1155 / 2015 / 916385$.

Zadnik, K., Mannis, M. J., Johnson, C. A. (1984). An analysis of contrast sensitivity in identical twins with keratoconus. Cornea, 3 (2), 99-103.

Zadnik, K., Mannis, M. J., Johnson, C. A., Rich, D. (1987). Rapid contrast sensitivity assessment in keratoconus. Amer. J. Optom. Physiol. Opt., 64 (9), 693-697.

\section{REDZES ASUMS UN KONTRASTJUTĪBA ATKARĪBĀ NO KERATOKONUSA VIRSOTNES ATRAŠANĀS VIETAS}

Daudzos iepriekšējos pētījumos ir pierādīts, ka pacientiem ar keratokonusu ir nozīmīgi samazināta kontrastredze, bet samazinājuma lielums ir atškirīgs dažādos pētījumos. Nevienā no šiem pētījumiem nav analizēts kontrastredzes pasliktinājums atkarībā no keratokonusa virsotnes atrašanās vietas, kas varētu izskaidrot dažādos pētījuma rezultātus. Pacientiem ar keratokonusu tika noteikts redzes asums un kontrastjutība ar FrACT testu. Kontrastjutība tika novērtēta, izmantojot vairākas frekvences: 1, 3, 5, 7, 9, 11, 13 un 15 cikli uz grādu. Pētījumā tika analizētas 24 acis ar keratokonusu. Kontrastjutība bija statistiski nozīmīgi zemāka pacientiem ar keratokonusa virsotni centrā nekā pacientiem ar keratokonusa virsotni perifērijā gan ar $(p=0,0078)$, gan bez brillıu korekcijas $(p=0,0078)$. Pacientiem ar keratokonusa virsotni centrā kontrastjutība bija statistiski nozīmīgi atškirīga, ja salīdzināja rezultātus ar un bez briḷlu korekcijas $(p=0,02)$, bet to nenovēroja pacientiem ar keratokonusa virsotni perifērijā $(p=0,06)$. Secinājumi: ja keratokonusa virsotne atrodas centrā, briḷ!̣ korekcija uzlabo kontrastjutîbu zemu telpisko frekvenču gadījumā (1,3 un 5 cikli uz grādu), bet nemaina to vidēju un augstu telpisko frekvenču gadījumā. Ja keratokonusa virsotne atrodas perifērijā, brillıu korekcija kontrastjutību nemaina. 